\title{
STRATEGI KONTEN DAKWAH SALAFI DI INSTAGRAM
}

\author{
Umi Kulsum, Deden Mauli Darajat \\ UIN Syarif Hidayatullah Jakarta \\ ummykulsum9@gmail.com
}

Naskah masuk: 31-12-2020, direvisi: 14-02-2021, diterima: 27-02-2021 dipublikasi: 17-03-2021

\begin{abstract}
ABSTRAK
Pertumbuhan akun-akun dakwah yang berprinsip pada ajaran Salafi di media sosial semakin berkembang secara masif. Instagram @khalidbasalamahofficial menjadi salah satu akun yang saat ini menyebarkan dakwah Salafi. Kehadiran akun tersebut memberi warna baru di tengah keberagaman akun-akun sekuler yang dapat menyesatkan umat. Kendati bersifat formalistik dengan menekankan prinsip dakwah Salafi, akun ini mampu menarik perhatian pengguna Instagram dengan melihat pertumbuhan followers yang terus meningkat. Penelitian ini bertujuan untuk mengetahui strategi yang dibuat oleh tim Khalid Basalamah (KHB) Digital Studio dalam memproduksi sebuah konten dalam menarik perhatian pengikutnya. Rumusan masalah yang diambil dalam penelitian ini meliputi bagaimana strategi tim official dalam menyajikan konten di akun @khalidbasalamahofficial yang menarik perhatian pengguna Instagram. Penelitian ini menggunakan metode kualitatif dengan studi kasus (case study) pada akun @khalidbasalamahofficial. Hasil penelitian menunjukkan bahwa pemanfaatan media Instagram efektif untuk menjangkau pengguna pemula dalam mempelajari dakwah Salafi. Strategi yang dilakukan oleh tim official ialah dengan memilih tema-tema ringan, tidak menimbulkan kontroversial. Sehingga dakwah Salafi yang disampaikan oleh Khalid Basalamah dapat mudah diterima oleh pengguna yang ingin memulai untuk mempelajari dakwah Salafi.

Kata kunci: Strategi, Salafi, Dakwah, Instagram, @khalidbasalamahofficial
\end{abstract}

\begin{abstract}
The growth of da'wa accounts based on Salafi teachings on social media is growing massively. Instagram @khalidbasalamahofficial is one of the accounts currently charged with Salafi preaching. The presence of this account gives a new color amid the diversity of secular accounts that can mislead people. Even though it is formalistic with the principle of emphasizing Salafi preaching, this account is able to attract the attention of Instagram users by seeing the growth of followers that continues to increase. This study aims to see the strategies made by the Khalid Basalamah (KHB) team of Studio Digital in producing content to attract the attention of their followers. The formulation of the problem taken in this study includes how the official team's strategy is to present content on the @khalidbasalamahofficial account that attracts the attention of Instagram users. This study uses a qualitative method with case studies on the @khalidbasalamahofficial account. The results showed that the use of Instagram media was effective in reaching novice users in learning Salafi da'wa. The strategy adopted by the official team, namely by choosing light themes, did not cause controversy. So that the Salafi da'wa delivered by Khalid Basalamah can be accepted by users who want to start learning Salafi da'wa.

Keywords: Strategy, Salafi,Da'wah, Instagram, @khalidbasalamahofficial
\end{abstract}

\section{PENDAHULUAN}

Kehadiran akun-akun dakwah di media sosial yang menyebarkan ajaran Salafi berkembang secara masif. Dinamika dakwah Salafi di Indonesia telah menemukan 
ruangnya secara bebas dengan mengikuti perkembangan media baru. Masih kerap menimbulkan perdebatan dalam penyebaran dakwahnya, Salafi agresif berdakwah melalui media untuk meminimalisir terjadinya resistensi dengan tradisi keislaman masyarakat. Media baru dianggap mampu mengambil perhatian masyarakat yang pada akhirnya dakwah Salafi dapat diterima. Ini menjadi fenomena baru di mana Salafi dengan ciri khas tradisionalnya memurnikan ajaran Islam mulai bergeser ke era modernitas melalui pemanfaatan teknologi digital. Salafi meyakini pemanfaatan media baru dapat membantu dalam mengembangkan dakwah Salafi kepada masyarakat luas.

Istilah Salafi diasosiasikan dengan al-salaf al-salih yang bermakna orang terdahulu yang saleh, yakni para ulama klasik yang menjadikan Al-Qur’an dan Hadis sebagai pedoman ajaran Islam. Pengertian Salafi dalam pengertian al-salaf al-shalih yang sebenarnya netral kemudian menjadi kontroversial ketika menjadi Salafisme yang bercorak sempit. Kontroversinya terletak pada pemberian makna al-salaf al-shalih sebagai pandangan dan sikap, dan prilaku yang merujuk dan mengikuti kelompok pertama generasi Islam yang shaleh secara literal-tekstual. Mulai dari praktik-praktik beragama sampai dengan cara berpakaian dan gaya hidup dalam pengertian yang literal-tekstual. Ajaran Salafi menolak menjalankan segala ibadah yang tidak dicontohkan oleh Nabi Muhammad sehingga konsisten dalam mengekspresikan dan mengamalkan Sunnah Rasulullah dalam kehidupan sehari-hari. Sejalan dengan Adeni (2020) dalam "Paradoks Komunikasi Dakwah Fundamentalis Salafi: Kasus Masjid Nurul Jam'iyah Jambi," perbedaan dengan praktik dakwah non Salafi tidak terlalu mengedepankan sisi formal dari ajaran Islam, ajaran Salafi justru mengarah pada ekspresi keislaman yang simbolik dan formalistik. Konsep dakwah yang dikemas oleh ajaran Salafi saat ini mendapat sambutan yang positif dari masyarakat. Hal ini didukung oleh kepiawaian da'i Salafi dalam menerapkan komunikasi yang beragam sejalan dengan perkembangan teknologi dan media komunikasi sehingga dapat mengajak orang untuk ikut bergabung dengan kelompoknya. Pentingnya sebuah komunikasi membuat kalangan Salafi mulai mengembangkan media komunikasi, misalnya stasiun televisi dan radio, website dan penerbit. Internet memberikan manfaat bagi agama dengan kemampuannya menjadi fasilitas dan alat baru bagi kepentingan agama dan pengikutnya.

Dalam pandangan Arnus (2018), fenomena penggunaan media online dalam mengakses berita dan membangun komunikasi interpersonal melalui jaringan media sosial melahirkan konsep baru dalam komunikasi yakni computer mediated communications (CMC). Pola ini dalam bidang dakwah berguna untuk mempermudah aktivitas dakwah untuk lebih memperluas kepada khalayak. Kalangan Salafi sejatinya sudah mempertimbangkan akan pentingnya internet sebagai media dakwah sehingga mereka membuat website, situs dan blog pribadi bahkan ada yang menggunakan jejaring sosial seperti Facebook, Twitter dan mailing list untuk menyebarkan dakwahnya. Dengan begitu pesan dakwah sudah bisa dinikmati oleh orang banyak dengan mudah dan cepat hanya dengan melihat alamat-alamat dalam situs internet tersebut.

Salah satu kanal yang saat ini masif dimanfaatkan oleh para da'i Salafi yakni media sosial. Materi yang disajikan dalam akun media sosial dikemas sedemikian rupa untuk menarik perhatian masyarakat terutama kalangan milenial dengan gaya pendekatan model anak muda. Saat ini penyampaian materi dakwah melalui media sosial dinilai lebih efektif ketimbang melalui siaran televisi konvensional. Mengutip pernyataan Ketua Pengurus Besar Nahdhatul Ulama (PBNU) Marsudi Suhud yang menyadari bahwa ada geliat berhijrah 
yang menjangkiti kalangan muda di wilayah perkotaan. PBNU juga ikut mengamati kebanyakan generasi milenial tersebut banyak yang hijrah karena pengaruh dakwah ulama Salafi, bukan dari NU. Marsudi menilai gaya dakwah ala Salafi bisa diterima anak muda karena para ustadznya pintar menangkap pangsa pasar lewat jalur media. New Media yang saat ini dimanfaatkan oleh pendakwah dalam menyebarkan ajarannya yakni media sosial Instagram. Saat ini Instagram merupakan media sosial yang paling banyak diakses oleh masyarakat Indonesia. Media sosial sebagai salah satu media online era digital yang memungkinkan para pengguna bisa berpartisipasi telah menciptakan sendiri bagi para penggunanya. Tak pelak, media sosial seakan menjadi kebutuhan primer bagi masyarakat era modern. Salah satu da'i yang menarik dan sedang naik daun saat ini dalam mengembangkan dakwahnya di internet adalah Khalid Basalamah. Nama Khalid Basalamah mulai dikenal masyarakat saat menyampaikan dakwahnya melalui kanal Youtube. Ciri khasnya dalam menyampaikan dakwah dengan tegas dan lemah lembut membuatnya semakin dikenal oleh masyarakat. Saat ini ia bersama timnya bernama KHB Digital Studio mengembangkan media onlinenya untuk menyampaikan pesan-pesan dakwah. Adapun media sosial yang dikembangkan oleh KHB Digital Studio adalah Youtube, Instagram, Facebook, Telegram, SoundCloud dan Twitter.

Peneliti memilih Instagram @khalidbasalamahofficial menjadi objek penelitian sebab akun ini mengalami pertumbuhan yang cukup signifikan dengan memiliki 2,1 juta pengikut dengan 2.458 konten yang telah diunggah. Akun tersebut mampu tumbuh eksis dan dipercaya oleh publik dalam kapasitasnya menyebarkan dakwah Salafi di era modernitas dengan banyaknya akun Instagram yang menyebarkan konten dakwah. Tim official berusaha menampilkan konten yang disukai oleh pengguna Instagram yang saat ini didominasi oleh kelompok usia muda. Berdasarkan penelitian Napoleon Cat periode Januari 2020 hingga Mei 2020 menyatakan bahwa usia dengan rentang 18 tahun hingga 34 tahun mencatatkan 25 juta pengguna Instagram. Dengan melihat potensi ini, urgensi dalam perkembangan dakwah di Instagram menjadi celah bagi para da'i dalam menyelaraskan pesan dakwahnya. Keberadaan content creator memainkan peran penting dalam pertumbuhan akun dakwah di Instagram. Dengan demikian, seorang pembuat konten dituntut memiliki keahlian dalam mengemas konten yang dapat menarik minat perhatian pengguna.

\section{METODE PENELITIAN}

Penelitian ini menggunakan metode penelitian studi kasus (case study) dengan pendekatan kualitatif desain deskriptif. Menurut Creswell (2014), pendekatan kualitatif yaitu untuk mengeksplorasi dan memahami makna yang oleh sejumlah individu atau sekelompok orang dianggap berasal dari masalah sosial. Penelitian dapat digunakan untuk memahami interaksi sosial misalnya dengan wawancara mendalam sehingga akan ditemukan pola-pola yang jelas. Sementara studi kasus adalah penelitian yang dilakukan terfokus pada suatu kasus tertentu untuk diamati dan dianalisis secara cermat sampai tuntas. Adapun bentuk penelitian ini bersifat online dan offline. Kedua cara tersebut bertujuan untuk memaksimalkan penelitian agar bisa terselesaikan di tengah pandemi Corona Virus Disease 2019 atau disingkat Covid-19. 


\section{Landasan Teoritis}

Pemanfaatan platform Instagram sebagai media dakwah semakin berkembang dengan bermunculannya akun-akun dakwah yang dikemas dengan konten kreatif. Instagram memang jauh lebih populer di kalangan anak muda. Hal ini ditunjukkan dalam popularitas platform naik lebih cepat seiring kebutuhan para pengguna media sosial. Sejak diluncurkan pada Oktober 2010, Instagram menjadi platform dengan banyak pengunjung di dunia untuk membagikan foto dan video yang banyak digemari oleh anak muda. Instagram adalah sebuah aplikasi media sosial yang memungkinkan pengguna untuk mengambil foto dan video, menerapkan filter digital (pemberian efek pada foto) dan membagikannya ke berbagai media sosial termasuk Instagram itu sendiri. Foto atau video yang dibagikan nantinya akan terpampang di feed pengguna lain yang menjadi follower Anda. Sistem pertemenan di Instagram menggunakan istilah following dan follower seperti di Twitter. Following berarti Anda mengikuti pengguna, sedangkan follower berarti pengguna lain yang mengikuti Anda. Selanjutnya setiap pengguna dapat berinteraksi dengan cara memberikan komentar dan memberikan respon suka terhadap foto yang dibagikan.

Di Indonesia sendiri dengan penduduk mayoritas Muslim, media sosial menjelma sebagai ruang publik Muslim untuk membagikan foto dan video ceramah tentang persoalan keagamaan. Fenomena ini muncul seiring dengan minat anak muda yang menggandrungi agama. Materi dakwah tidak lagi monoton yang dikemas menarik dalam bentuk foto dan video, sehingga dengan hal tersebut audience lebih mudah dalam melihat dan mendengar pesan-pesan dakwah di Instagram. Platform Instagram merupakan media sosial yang paling populer di dunia saat ini. Dengan kelebihan tersebut, menjadi ladang yang potensial dalam menyampaikan pesan dakwah. Terlebih, menurut pandangan Nisa (2018), Instagram juga tengah digemari oleh pemuda Indonesia dalam mengakses ilmu pengetahuan agama. Instagram memiliki efek signifikan terhadap cara pandang pemuda Muslim Indonesia dalam memahami agama dan menekankan identitas (saleh) mereka dan tujuan hidup. Konsep jejaring sosial dengan "follow", "like" foto, dan "popular" yang menjadikan Instagram semakin banyak penggunanya. Hanya saja kelemahan Instagram ialah tidak hanya terbatas dua konteks saja yakni foto dan video sehingga pembuat konten dituntut kreatif dalam menyajikan konten. Selain itu durasi video juga terbatas hanya maksimal 1 jam yang terdapat di fitur Instagram TV atau IGTV. Sehingga audience tidak bisa berlama-lama untuk menonton video yang ditampilkan di Instagram.

Dalam proses dakwah, Silvia (2019) dalam jurnal Strategi Content Creator pada Dakwah di Media Sosial (Studi Kasus pada Akun Instagram @pejuang.mahar melihat bahwa konten-konten bermuatan Islam dengan penyajiannya yang kreatif dan menarik banyak diminati oleh pengguna lain. Sehingga kegiatan dakwah dan konten-konten Islami dalam Instagram menjadi konten-konten yang disukai dan menjadi tren di masyarakat. Konten Islami yang kreatif membuat masyarakat tidak bosan untuk menikmati dan bahkan ikut membagikan konten dakwah tersebut ke media sosial lain. Pada intinya isi pesan Instagram memberikan manfaat bagi penggunanya.

\section{Keunggulan Instagram untuk Media Dakwah}

Platform Instagram saat ini menjadi salah satu media pilihan para da'i untuk menyampaikan pesan-pesan dakwahnya. Instagram dinilai lebih efektif dan efisien dilihat 
dari cepatnya penyebaran informasi ke berbagai penjuru. Sehingga mempermudah para mad'u untuk mendapatkan informasi keagamaan. Terlebih dakwah melalui Instagram dapat dinikmati segala keadaan tanpa terbatas ruang dan waktu seperti halnya datang ke majelis untuk mengikuti kajian. Pengguna Instagram terutama di Indonesia bertumbuh secara signifikan. Data We Are Social pada Januari 2020 menunjukkan pengguna Instagram mencapai 79\% dari jumlah populasi di Indonesia. Jika diakumulasikan pengguna Instagram di periode ini tercatat mencapai 63 juta orang. Jika dibandingkan dengan tahun 2017 Instagram baru memiliki 45 juta pengguna aktif. Dengan jumlah pengguna yang besar ini menjadi kesempatan dan peluang da'i untuk memanfaatkan media Instagram agar menjangkau ke lebih banyak mad'u. Adapun pengakses Instagram juga didominasi usia muda 18 tahun sampai 24 tahun sebesar 37\% sedangkan di usia rentang 25 tahun sampai 34 tahun sebesar $33,7 \%$.

Dengan pertumbuhan yang tinggi tersebut beragam alasan masyarakat Indonesia senang berselancar di Instagram ialah salah satunya platform tersebut mengandalkan visual. Orang Indonesia sendiri lebih tertarik dengan gambar yang menarik dibandingkan dengan membaca. Selain itu, banyak fitur yang inovatif dan dapat dinikmati oleh pengguna. Fitur yang terus berkembang tersebut menjadi alasan pengguna betah berlama-lama menggunakan Instagram. Dengan alasan ini, para pembuat konten dakwah menyasar Instagram dengan mengemas konten yang dapat menarik perhatian melalui foto dan video. Daya tarik fitur Instagram ini yang dapat memudahkan pengguna dalam memahami konten dakwah yang dibagikan oleh para da'i. Dibandingkan Youtube, Instagram menjadi platform pilihan warganet untuk mengakses video dakwah di media sosial. Sebab durasi yang ditawarkan oleh Instagram lebih singkat dibanding Youtube. Jika pembuat konten ingin memperkenalkan produk baru misalnya, Instagram dinilai lebih efektif untuk memperkenalkan produk baru tersebut dikarenakan kesegeraan Instagram menjadi tepat untuk memunculkan awarness tentang produk ke target audience. Sedangkan jika ingin review mendalam mengenai produk tersebut, Youtube menjadi platform yang cocok.

Khalid Basalamah (KHB) Digital Studio merupakan kanal digital yang dicetuskan oleh Khalid Basalamah dan kawannya bernama Diarto pada tahun 2013 yang merupakan lembaga non profit. KHB Digital Studio masih satu naungan di bawah PT Gazwah Enterprise. Adapun bisnis di bawah naungan Gazwah Enterprise terdiri atas Uhud Tour, Ajwad Store, Ajwad Resto, Pustaka Ibnu Zaid. Tim KHB Digital Studio terbagi menjadi tiga divisi yaitu tim produksi studio, tim lapangan dan tim kreatif yang berjumlah 14 orang. Sementara lembaga non profit lainnya yang didirikan oleh Khalid Basalamah adalah Sedekah Kreatif, Mawaddah Indonesia. Pengembangan media sosial yang digunakan pertama kali untuk berdakwah adalah Youtube. Tepatnya pada 7 Februari 2013, channel Youtubenya diberi nama Khalid Basalamah Official. Adapun video pertama yang diunggah ialah Sejarah Nabi Muhammad. Pengembangan dakwah KHB Digital Studio tidak hanya terbatas video saja, namun dibuat sebuah website official www.khalidbasalamah.com untuk mengupload artikel-artikel yang ditulis oleh Khalid Basalamah. Tak hanya itu saja, Khalid Basalamah dan tim juga membuat aplikasi KHB di Appstore. Aplikasi ini berisikan konten video-video potongan kajian, jadwal kajian, pengingat waktu sholat dan lainnya. Hingga kini, KHB Digital Studio semakin ekspansif dalam mengembangkan dakwahnya melalui media sosial. Seperti misalnya membuat konten berupa motion graphic, poster dakwah dan sebagainya. Terbaru, tim KHB Digital Studio sedang mengembangkan channel Gazwah TV. 


\section{Strategi Content Creator Memproduksi Konten}

Keberadaan content creator sangat diperlukan untuk memproduksi konten secara konsisten agar menarik perhatian audience. Strategi yang tepat dari seorang pembuat konten menjadi nilai plus agar konten yang diproduksinya dapat menjadi pilihan para pengguna. Strategi konten yang efektif akan membantu untuk mendapatkan audience yang ideal. Untuk itu, seorang pembuat konten harus memahami strategi dalam membuat konten di antaranya:

\section{a. Tampilan Konten yang Informatif}

Dalam membuat konten di Instagram, Ceambur (2020) berpendapat bahwa seorang pembuat konten harus memberikan unggahan yang informatif. Artinya, informasi tersebut dibutuhkan oleh audience yang memberikan manfaat setelah melihatnya. Informasi yang disajikan bisa mendidik, menghibur dan memotivasi audience. Seorang pembuat konten dituntut untuk konsisten menyampilkan konten sesuai dengan tujuan yang biasanya terdapat di bio awal Instagram. Unggahan tidak boleh dipenuhi terlalu banyak konten promosi sebab audience akan bosan dan akhirnya tidak mengikuti akun Instagram tersebut. Tampilan audio dan visual merupakan hal utama yang harus diperhatikan oleh audience. Tampilan konten yang maksimal akan menaikkan jumlah pengunjung yang mengakses unggahan tersebut. Menurut Silvia (2019), media audio visual ialah suatu media yang terdiri atas media visual yang dihubungkan dengan media audio sehingga memungkinkan terjadinya komunikasi dua arah. Dengan demikian, antara audio dan visual adalah perpaduan yang saling mendukung satu sama lain antara gambar dan suara yang dapat menarik perhatian audience. Maka itu diperlukan keahlian memadukan antara gambar dan suara dalam sebuah konten. Seorang content creator harus menyelaraskan antara video dan audio sesuai dengan konten yang akan disampaikan. Pembuat konten juga harus memiliki pengetahuan dalam merancang konten yang dibuat sehingga memberi efek kepada penonton yang menikmati unggahan tersebut. Selain audio visual, pemilihan warna dalam merancang konten juga harus disesuaikan dengan materi konten yang akan disampaikan. Hal ini untuk membangun emosi konten tersebut agar sesuatu yang disampaikan lebih hidup dan menimbulkan kesan di hati audience. Sebuah penelitian dari WebDam mengenai visual di media sosial bahwa $60 \%$ dari brand terkenal di Instagram menggunakan filter yang sama pada setiap kontennya. Dengan menggunakan filter yang sama, tampilan konten akan mudah dikenali oleh followers. Jika semakin dikenali, semakin besar juga kemungkinan followers akan menyukai konten tersebut dan ramai berinteraksi di kolom komentar.

\section{b. Identifikasi Konten yang Diproduksi}

Menurut pendapat Tuten (2016) dalam bukunya Social Media Marketing mengungkapkan, seorang pembuat konten harus merancang konten untuk memiliki gambaran yang jelas tentang apa yang saat ini menjadi topik menarik. Seperti pemilihan tema dan topik yang terlebih dahulu harus diidentifikasi oleh pembuat konten dengan mempertimbangkan sesuatu yang dibutuhkan dan sesuai minat audience. Sehingga, jika apa yang dibutuhkan audience tersedia, secara otomatis akan menaikkan jumlah pengunjung yang mengakses unggahan tersebut. Saat membuat konten, content creator harus memikirkan tiga hal yakni tahap kesadaran, pertimbangan dan keputusan. Ketiga hal tersebut akan membawa audience untuk percaya dan setia untuk tetap menjadi konten pilihan yang mereka butuhkan. 


\section{c. Membuat Jadwal Unggah Konten}

Setelah memutuskan tema konten, Ceambur (2020) menguraikan langkah selanjutnya adalah membuat kalender rencana unggah konten. Kalender ini akan membantu pembuat konten memvisualisasikan apa yang akan disajikan. Membuat jadwal untuk memproduksi konten adalah salah satu strategi seorang content creator dalam mengatur waktu mengunggah konten. Dengan memiliki waktu unggah yang rutin tidak mengganggu followers dengan update yang berlebihan. Biasanya pembuat konten akan menganalisis kebiasaan pengguna dalam mengakses Instagram pada waktu-waktu tertentu. Pengaturan waktu unggah ini dinilai dapat meningkatkan engagement serta menarik perhatian audience. Konsisten dalam mengunggah konten juga hal yang penting dan harus diperhatikan pembuat konten. Saat membuat jadwal unggahan, seorang pembuat konten juga harus mempertimbangkan beberapa hal seperti menentukan komitmen dengan jumlah unggahan konten setiap harinya, jadwal jam tayang yang efektif saat banyak audience sedang online dan menggunakan Instagram. Waktu terbaik untuk mengunggah konten dapat membantu keberhasilan dalam menjaring audience. Selain itu, pembuat konten juga harus menentukan alat penjadwalan otomatis untuk membantu proses perencanaan mengunggah konten dengan waktu yang telah ditentukan. Sebuah penelitian yang dilakukan oleh Latergram terhadap Social Media Manager, memunculkan fakta yang cukup menarik mengenai waktu untuk mengunggah konten di Instagram. Pada 2018, waktu terbaik unggah konten yakni waktu makan siang antara pukul 11.00 WIB sampai $13.00 \mathrm{WIB}$ dan kemudian malam hari pukul 19.00 WIB sampai 21.00 WIB. Dengan waktu senggang tersebut dimanfaatkan oleh pembuat konten untuk mengunggahnya secara konsisten agar banyak dilihat oleh pengikut.

\section{d. Menetapkan Frekuensi Unggah Konten}

Seorang pembuat konten perlu memahami cara kerja algoritma Instagram untuk melihat jangkauan pengguna yang melihat konten tersebut. Saat mengunggah, Instagram menampilkan konten secara organik sekitar 1\% sampai $2 \%$ audience. Algoritma Instagram lebih menyukai konten yang baru. Setiap kali mengunggah konten baru, Algoritma Instagram menganggap konten lama tidak relevan lagi. Sehingga unggahan baru akan lebih diutamakan daripada unggahan lama. Untuk itu seorang pembuat konten disarankan konsisten mengunggah dua sampai tiga konten berkualitas per minggunya. Seperti juga memperhatikan bagaimana antar pengguna berinteraksi dengan konten yang disajikan baik dalam meninggalkan suka, komentar atau berbagi. Ada beberapa cara untuk memperkuat konten Instagram untuk menjangkau pasar secara luas di antaranya promosikan konten Instagram kolaborasi dengan platform lain untuk menjangkau lebih banyak target audience, bekerja sama dengan influencer, membuat tagar atau hashtag. Tooby (2020) berpendapat bahwa pemilihan teks untuk membuat hashtag juga harus diperhatikan untuk membantu memperluas jangkauan audience yang melihat. Melalui pencantuman hashtag, memungkinkan foto dan video akan dilihat oleh lebih banyak orang dibanding dengan tidak menggunakan hashtag.

Dalam membuat konten di Instagram, perlu juga diperhatikan mengenai teks dan caption yang akan dituliskan (Ceambur, 2020). Penggunaan kata yang mudah dipahami dan kekinian dapat menjadi daya tarik tersendiri bagi para audience. Selain itu, agar konten yang 
dibuat akan banyak dijangkau seorang pembuat konten juga harus membuat unggahan menggunakan pola penulisan yang memerhatikan Search Engine Optimization (SEO). SEO dikenal sebagai salah satu cara meningkatkan di mesin pencari dan mengarahkan traffic ke dalam sebuah situs. SEO merupakan teknik yang dapat merekayasa agar mesin pencarian konten yang ditampilkan ada pada urutan teratas. Dengan pencarian yang mudah ini pengunjung menjadi ramai yang mengakses konten tersebut. Tidak hanya memerhatikan tampilan gambar sebuah konten, seorang content creator juga perlu melihat caption yang dibuat. Caption merupakan penulisan kalimat di bawah unggahan gambar dan video yang memiliki tujuan tertentu. Salah satunya adalah untuk memperjelas apa yang ingin disampaikan pada konten tersebut. Tujuan lainnya ialah untuk meringkas unggahan untuk memberi gambaran atau deskripsi dari sudut pandang penulis. Beberapa strategi dalam membangun caption pada unggahan adalah membuat teks secara ringkas dan jangan terlalu panjang, selain itu perlu juga memerhatikan demografis audience tersebut untuk membangun interaksi dengan pengikut agar konten tersebut disukai.

\section{HASIL DAN PEMBAHASAN}

Instagram @khalidbasalamahofficial merupakan salah satu akun media sosial yang dikelola oleh Khalid Basalamah dan tim KHB Digital Studio untuk mensyiarkan dakwahnya. Pamor Instagram yang sedang naik daun turut dimanfaatkan untuk memikat perhatian para pengguna dengan meramu konten dakwah yang menarik. Sebab semakin menarik konten yang dibuat maka semakin banyak pula orang-orang yang ingin mengikuti akun tersebut. Selain konten yang menarik, peran content creator dalam hal ini tim KHB Digital Studio yang memproduksi setiap konten dakwah Khalid Basalamah juga menjadi pendukung keberhasilan dakwahnya di media sosial. Bertumbuhnya jumlah followers Instagram @khalidbasalamahofficial dilatarbelakangi oleh keunggulan yang dimiliki dibanding dengan akun-akun yang juga menawarkan produk-produk dakwah Salafi. Konten yang diproduksi oleh akun @khalidbasalamahofficial menawarkan kemampuannya untuk berkomunikasi melalui persepsi yang mudah digunakan dengan kecepatan yang dimilikinya. Peneliti melihat, struktur organisasi KHB Digital Studio yang tersistem dengan pembagian tugas yang jelas juga menjadi katalisator yang membuat dakwah Khalid Basalamah di media sosial semakin eksis. Berikut ini adalah paparan hasil penelitian strategi yang digunakan oleh tim KHB Digital Studio dalam mengelola akun @khalidbasalamahofficial dalam berdakwah di media sosial Instagram, yaitu:

\section{Instagram sebagai Media Pembuka untuk Mempelajari Ilmu Agama}

Platform Instagram yang kini tengah diminati turut dimanfaatkan oleh tim KHB Digital Studio dalam pengembangan dakwahnya. Dengan melihat potensi audience yang tinggi, tim meramu strategi yang berbeda dengan media sosial eksisting yang dikembangkan. Youtube merupakan media sosial yang pertama kali digunakan oleh Khalid Basalamah berdakwah secara digital. Melalui Instagram, tim ingin lebih mendongkrak jangkauan dakwahnya yang hanya terpusat pada audience yang benar-benar ingin menuntut ilmu. Namun, semua kalangan yang berselancar di media sosial adalah sasarannya. Tim KHB Digital Studio memanfaatkan media Instagram yang sedang banyak digunakan oleh masyarakat. Faktor ini yang mendorong tim official untuk meraup potensi audience yang lebih banyak lagi guna memperluas cakupan dakwah. Eksistensi dakwah Khalid Basalamah memang diawali dari 
channel Youtube, namun melihat kebutuhan audience pengguna Instagram menyukai konten-konten dengan durasi pendek, tim official berusaha menyajikan konten yang memang bisa dinikmati di Instagram.

"Hasil ceramah-ceramah yang kita lihat menarik saat di Youtube maka kita bangun ke Instagram. Nah di Instagram menarik kita bangun ke Facebook. Jadi Instagram sendiri turunan dari Youtube. Nah dari konten-konten itu banyak orang yang share dengan cara menyertakan sumber sehingga orang yg lihat tahu sumbernya dari mana dan langsung melihat akun kami jadi mereka ikut ke sumbernya. Dari situ juga kita sangat berterima kasih kepada relawan-relawan yang bantu dakwah Khalid Basalamah." Dengan demikian tim official membedakan waktu tayang konten yang ada di Instagram dengan Youtube agar audience yang melihat tidak merasa bosan dengan konten yang ada di Instagram. Tim mencoba menarik banyak pengikut melalui Instagram yang pada akhirnya mereka ingin mendalami isi ceramah dengan membuka channel Youtube yang menyajikan video dengan durasi panjang. Kita memang bedakan waktu unggahan di Instagram dan Youtube, biasanya kontennya terpisah. Supaya gak bosan." (Wawancara tim KHB Digital Studio, 11 Juni 2020).

Dengan demikian, melalui Instagram Khalid Basalamah dan tim official ingin menyajikan konten ringan melalui Instagram, sasaran dakwahnya tertuju pada pengguna yang memang belum mengenal dakwah Salafi maupun yang baru mempelajarinya. Sementara, ketika pengguna ingin mendalami pemahaman ilmu agamanya, pengguna mengakses Youtube yang menyajikan konten dakwah dengan durasi lebih panjang. Diakui Khalid Basalamah, prinsipnya dalam menyebarkan dakwah tidak hanya terfokus pada golongan tertentu, namun Ia menginginkan orang awampun bisa memulai untuk mempelajari ilmu syar'i dengan kemasan yang ringan. Tim official dan Khalid Basalamah ingin keberadaan akun Instagram-nya dapat membuat audience tergugah untuk mempelajari ilmu agama yang kemudian nantinya audience ingin mendalami keilmuan yang kontennya telah disediakan di platform Youtube. Dalam mengunggah konten, tim official membedakan materi yang akan disajikan di Instagram dan Youtube. Tim melihat perbedaan audience kedua media sosial tersebut. Khusus untuk Instagram, tim akan memotong materi ceramah Khalid Basalamah menjadi dua segmen yakni satu menit sampai tiga menit dan satu menit sampai lima menit. Ini menjadi bagian strategi tim official agar menarik perhatian followers. Begitupun dengan jam tayang antara Instagram dan Youtube juga sengaja dibedakan. Berbeda dengan Instagram, unggahan di Youtube perlahan mulai berubah strategi dengan kemasan konten yang durasinya tidak terlalu panjang. Semisal semula hanya mengunggah tiga konten dengan durasi panjang selama satu hari saat ini setidaknya enam konten di Youtube telah diunggah dengan video yang berdurasi lebih pendek.

\section{Pemilihan Judul dengan Bahasa Persuasif dan Tidak Kontroversial}

Tim KHB Digital Studio sengaja membuat judul-judul di akun @khalidbasalamahofficial yang mudah dipahami oleh audience. Sebab, karakteristik pengikut akun tersebut berasal dari semua kalangan. Untuk menjawab kebutuhan tersebut, judul-judul konten yang ringan menjadi pilihan agar pengikut tertarik untuk membuka konten tersebut dan menyerap isi ceramah yang disampaikan. Bahasa persuasif yang dibuat berusaha untuk meyakinkan audience agar melakukan sesuatu yang dikehendaki oleh 
Khalid Basalamah. Dengan bahasa yang persuasif tersebut dapat membangkitkan kegiuran audience untuk meyakini apa yang diucapkan oleh sang Ustadz. Tim juga memilih juduljudul yang tidak kontroversial demi menghindari perdebatan antar pengikut.

"Kalau judul memang tim Digital Studio yang buat. Kita dalam pemberian judul tentu jadi perhatian judul yang tidak membuat polemik tidak menyinggung seperti menyerang suatu kelompok atau suatu orang tapi lebih bersifat judul-judul yang universal atau umum jadi misalkan kaya beberapa konten di Instagram kita misalnya godaan selingkuh setelah menikah harusnya bisa membuat selingkuh itu berbahaya. Tapi kita melihat itu seperti menjudging. Kita lebih dari hati ke hati kasih judulnya supaya orang tergugah. Kita coba berinteraksi dengan followers. Dan kita tidak memilih dengan kata-kata yang langsung oh ini haram ini, masuk neraka dan sebagainya. Lebih buat konten-konten yang sesuai dengan metode dakwah ustadz Khalid penyampaian dakwahnya dari hati ke hati kita sesuaikan judulnya pun demikian." (Wawancara tim KHB Digital Studio, 11 Juni 2020).

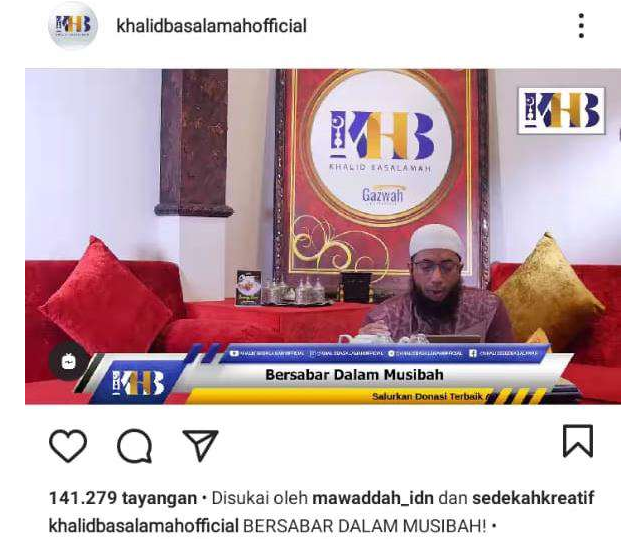

\section{Gambar 1.1 Judul-Judul Konten Dakwah yang Diproduksi oleh Akun @khalidbasalamahofficial}

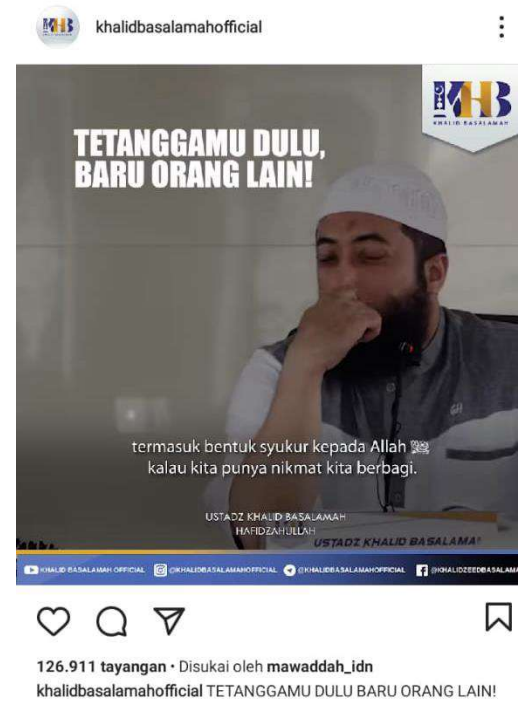

Gambar 1.2 Judul-Judul Konten Dakwah yang Diproduksi oleh Akun @khalidbasalamahofficial 
Dari kedua judul-judul konten tersebut, Khalid Basalamah berusaha mengajak para pengikutnya untuk berasabar dalam musibah dan mendahulukan kepentingan tetangga dibanding orang lain yang jauh. Kedua judul tersebut menggunakan bahasa persuasi. Pengikut diajak untuk bersabar atas musibah yang terjadi meskipun ujian tersebut terasa berat untuk dihadapi. Khalid Basalamah pun mengajak kepada pengikut untuk tidak membalas keburukan orang lain dan memilih untuk mengontrol emosi dan bersabar. Dengan sabar, seorang hamba akan diganjar pahala yang berlimpah. Demikian dengan judul mengutamakan tetangga sebab merekalah yang paling dekat memiliki hak untuk diberikan sesuatu kepadanya. Dengan mendahulukan tetangga Khalid menegaskan ini merupakan bentuk syukur dan dapat diganjar pahala oleh Allah. Berdasarkan observasi peneliti selama kurang lebih tiga bulan untuk memantau akun@khalidbasalamahofficial banyak temuan yang didapat perihal judul yang dibuat oleh tim official. Ada beberapa pola khas dalam judul yang dirancang pada setiap kontennya. Pertama, pemilihan judul dengan kata-kata yang mudah dipahami oleh semua kalangan pengguna Instagram. Dalam artian pemilihan kata-kata yang sederhana dan tidak menimbulkan polemik. Kedua, strategi tim official dalam memberikan judul ingin berupaya untuk berinteraksi dengan pengguna sehingga judul yang dibuat juga mempertimbangkan pengetahuan followers Instagram agar dipahami oleh kalangan yang awam. Selain itu, pemilihan bahasa persuasif pada setiap judulnya juga menjadi daya tarik tersendiri untuk dilihat oleh para pemirsanya. Ketiga, penggunaan kata-kata yang membuat orang tergugah untuk memahami pesan dakwah pada konten tersebut. Adapun contoh judul-judul konten yang dibuat oleh akun @khalidbasalamahofficial yang terlihat paling banyak dilihat ditonton yakni:

a. Dalam Pernikahan, Lakukan Semua Karena Allah

b. Adab Biologis Dalam Islam

c. Termasuk Sunnah Nabi Sebelum Tidur

d. Romantis Dalam Islam Yang Benar

e. Jangan Menonton Video Porno

Dengan strategi tersebut, tim official memahami betul judul merupakan faktor penting dalam mendukung konten tersebut disukai atau tidak oleh para audience. Terlebih, judul yang dibuat akan mendorong orang-orang mengkilk konten tersebut. Tujuan tim KHB Digital Studio dalam membuat judul tidak hanya klik bait namun ingin meninggalkan kesan setelah melihat atau menonton konten tersebut. Dengan demikian setelah melihat konten tersebut hingga selesai, followers mendapatkan pengetahuan baru yang manfaat dan pada akhirnya akan diaplikasikan di dalam kehidupan nyata. Dapat disimpulkan, strategi penggunaan judul yang sederhana, menggunakan bahasa persuasif dan tidak menimbulkan polemik mendorong ketertarikan audience untuk mengikuti akun @khalidbasalamahofficial dengan saat ini telah memiliki 2,1 juta followers.

\section{Pemilihan Materi Dakwah yang Berkaitan dengan Kehidupan Sehari-hari}

Secara garis besar ada tiga bahasan yang menjadi tema besar dakwah Khalid Basalamah di Instagram, yakni:
a. Sirah Nabawiyah (Kisah-Kisah Nabi)
b. Akhlak
c. Rumah Tangga dan Pernikahan

Ketiga tema-tema tersebut dilihat tim KHB Digital Studio yang paling disukai oleh para pengikut akun @khalidbasalamahofficial. Dengan demikian, penulis melihat frekuensi tema-tema tersebut juga lebih sering diunggah ketimbang tema-tema lainnya. Seperti 
halnya tema rumah tangga dan pernikahan banyak disajikan di akhir pekan karena jumlah penonton terlihat lebih banyak.

"Sabtu dan Ahad safari dakwah artinya konten-konten yang sifatnya pembahasan tematik seperti manajemen rumah tangga dan rahasia rezeki untuk pemabahsan yang telah disusun Ustadz tapi sifatnya tematik. Ini kenapa ditaruh Sabtu ini untuk pembahasan santai orang-orang yang mau coba mengenal agama dengan kajian yang sifatnya tematik. Kalau kitab Riyadussalihin ini sudah pasti untuk penuntut ilmu yang ingin belajar tapi kalau yang awam bingung ini kitab apa ini. Sehingga dari tematik Sirah Nabawiyah dan tematik ini kita berharap orang awam mengenal dengan cara mengenal nabinya dulu nih sejarahnya. Lewat kajian tematik tersentuh akhirnya lari ke kajian kitab untuk menjadi penuntut ilmu insyaaAllah." (Wawancara tim KHB Digital Studio, 11 Juni 2020).

Melalui tema-tema ringan yang disukai oleh followers membuat daya tarik tersendiri akun @khalidbasalamahofficial disukai oleh semua kalangan. Bahkan, menurut analisa penulis, kalangan pengikut bukan hanya yang sudah berhijrah menjadi penuntut ilmu namun justru banyak terdapat orang awam yang bahkan belum memahami ilmu agama juga banyaknya remaja. Tema-tema tersebut diakui oleh tim official menjadi ciri khas tertentu yang disajikan oleh akun @khalidbasalamahofficial dibanding akun dakwah Salafi lainnya. Tim KHB Digital Studio juga berkomitmen akan menyiarkan dakwah-dakwah yang sifatnya memang banyak dibutuhkan oleh masyarakat sehingga pesan tersebut bisa tersampaikan dengan baik. Ke depan, tema-tema ini masih menjadi unggulan di akun @khalidbasalamahofficial. Khalid Basalamah dan tim official juga mengikuti prinsip-prinsip dakwah Salafi dalam memproduksi kontennya.

"Saya akan kerucutkan bahasan-bahasan spesialis saya di dakwah, sepertinya saya lebih cocok masuk ke akidah, sehingga saya menanamkan masalah akidah. Kedua, kajian-kajian sejarah Sirah sahabat 25 Nabi. Ketiga, tema-tema seperti pelembutan hati Tazkiyatun Nafs syurga neraka, dan fokus di situ. Ini umum oleh umat diterima karena kalau tidak pasti akan ada celah. Kemarin itu saya bahas semuanya termasuk fikih saya membahas kitab Bulughul Maram itu memang bisa dibahas tapi menurut saya biarlah teman-teman lain di bidangnya. Saya bahas tiga poin itu efeknya lebih besar. Karena saya melihat di Sirah bisa masuk juga ke kajiankajian lain. Di akidah juga gitu, di pelunakan hati juga bisa lebih tepat. Supaya bisa saling melengkapi sehingga saya bisa melihat oh Allah mudahkan di sini. Strategi ke depannya ke situ. Lebih kepada spesialis nya." (Wawancara Khalid Basalamah pada 22 Juni 2020).

Sama halnya dalam memasarkan produk agar pembeli tertarik, konten dakwah yang diunggah di Instagram juga harus memiliki strategi nilai jual agar penonton tertarik untuk melihat konten tersebut. Akun @khalidbasalamahofficial mengoptimalkan strategi marketing di Instagram dalam meramu sebuah konten yang dapat menarik followers dengan status profil bisnis. Dengan mengubahnya ke profil bisnis, banyak kemudahan dan manfaat yang didapat oleh pemilik akun di antaranya dapat mencantumkan nomor telepon, alamat e-mail, kontak ataupun alamat perusahaan. Selain itu, pemilik akun juga bisa memnfaatkan fitur insight untuk menganalisa target penonton sehingga menjadi acuan untuk maksimal memosting sebuah konten. Pemilihan sebuah konten yang akan diunggah 
juga harus melalui pertimbangan terlebih dahulu agar konten tersebut mendapat banyak perhatian dari audience. Dengan begitu tujuan yang ingin disampaikan bisa tepat sasaran. Setelah memantau, peneliti melihat akun @khalidbasalamahofficial memilih konten dengan tema yang berbeda-beda agar para pengikut setia tidak bosan. Dengan demikian tim official membutuhkan pemikiran panjang sebelum memunggah konten.

"Tujuan kami untuk banyak orang yang mendapatkan hidayah. Sasaran dakwah ini bagaimana dakwah ini cepat menyebar. Saya berjalan alami. Inilah ciri khas dan retorika saya. Becanda pada tempatnya. Materi yang padat mereka keluar bawa ilmu. Kalau untuk strategi khusus tidak berfikir ke sana. Saya berfikir sederhana." (Wawancara Khalid Basalamah, 22 Juni 2020).

Selain pesan dakwah yang dibawakan oleh Khalid Basalamah yang menyentuh para mad'unya, followers juga merasa seringkali mendapatkan jawaban dari pertanyaan mereka melalui konten-konten di Instagram @khalidbasalamahofficial. Berbeda bila datang ke kajian, biasanya pendengar akan sulit bertanya dengan keterbatasan waktu yang disediakan. Materi konten yang terdapat di akun Instagram @khalidbasalamahofficial merupakan potongan-potongan video panjang dari akun Youtube Khalid Basalamah Official. Tim KHB Digital Studio akan memilih materi konten yang menarik dari akun Youtube untuk diangkat ke akun Instagram dengan durasi yang lebih pendek. Selain itu, tim digital juga membuat waktu unggah secara rutin agar konten tersebut dapat tersampaikan dengan tepat sasaran di jam-jam yang memang sudah dilihat audience akan mengakses Instagram. Dalam meramu sebuah konten, tim KHB Digital Studio juga melakukan rapat redaksi untuk menentukan materi apa saja yang sekiranya akan diangkat di akun media sosialnya. Tim digital memilih untuk tidak mengikuti latah terhadap isu-isu yang sedang viral kemudian dikaitkan dan diangkat menjadi sebuah materi konten. Tim mempertimbangkan kebermanfaatan konten tersebut dan tidak gegabah dalam menentukan materi konten. Tim digital seringkali menjawab saran followers yang mengirimkan pesan melalui direct message (DM) untuk menaikkan materi konten yang memang belum pernah dibahas. Hanya saja, peneliti melihat interaksi antara tim akun @khalidbasalamahofficial dengan audience bersifat pasif sehingga tidak terlihat kedekatan dengan para pengikut.

"Kalau yang sifatnya cuma isu terhadap satu individu kita tidak pernah gubris karena arahnya gak ke situ kecuali pandemi yang masif baru kita kaitkan isunya kita bahkan buatkan sajian konten itu judulnya Corona dan Solusinya. Kita buat kajian rutin selama wabah berlangsung membahas berdasarkan yang diajarkan oleh Nabi. Ustadz lebih membahas kepada riwayat yang sahih. Jadi dari situ kita melihat kalau mau melibatkan isu isu tertentu kita juga memilih. Manfaat dan mudharatnya kita hitung benar-benar." (Wawancara tim KHB Digital Studio, 11 Juni 2020).

Dalam mengemas konten dakwah di Instagram, dapat disimpulkan bahwa Khalid Basalamah sengaja membuat isi materi yang disampaikan lebih pendek dan sederhana sehingga mudah dipahami untuk semua kalangan termasuk para pemula yang baru memulai mengenal ilmu syar'i. Khalid Basalamah dalam berdakwah menggunakan kalimatkalimatyang mudah diterima oleh kalangan masyarakat. Ia seringkali memberikan hal-hal yang seringkali terjadi untuk menjadi contoh dalam membahas masalah. Gaya dakwah 
Khalid berusaha untuk merangkul dan mengambil jiwa pemirsanya dengan pemilihan bahasa yang tepat. Dengan teknik penyampaian yang santai dan meninggalkan kesan yang membuat tertarik pendengar setianya. Dalam berdakwah, Khalid Basalamah sengaja tidak memfokuskan kalangan tertentu berbeda dengan Hanan Attaki misalnya yang lebih banyak dakwahnya hanya untuk kalangan milenial. Khalid merasa apa yang ia sampaikan bisa melingkup oleh semua segmen tanpa terkecuali. Dengan target semua kalangan membuat dakwah Khalid juga bisa diterima dengan baik. Terkadang, Khalid juga menyelipkan guyonan untuk mencairkan suasana dakwahnya hanya saja tidak berlebihan dan melihat situasi dan kondisi. Ciri khas intonasi Khalid juga menjadi daya tarik tersendiri bagi masyarakat yang membedakan dakwahnya dengan para asatidz lain.

\section{Tampilan Konten yang Kebaruan}

Dalam pembuatan setiap kontennya, akun @khalidbasalamahofficial memiliki karakteristik dan ciri khas tersendiri dibanding akun-akun dakwah lainnya. Sebagai media Islam Salafi, akun @khalidbasalamahofficial berkomitmen untuk membuat konten yang tidak melanggar syari'at. Kendati tanpa musik dan gambar kartun secara utuh tidak menjadi kendala bagi tim KHB Digital Studio dalam membuat konten, namun justru menjadi tantangan untuk membuat sebuah konten yang berbeda dengan kemasan yang menarik namun tetap pada koridor yang dibolehkan dalam ajaran Salafi.

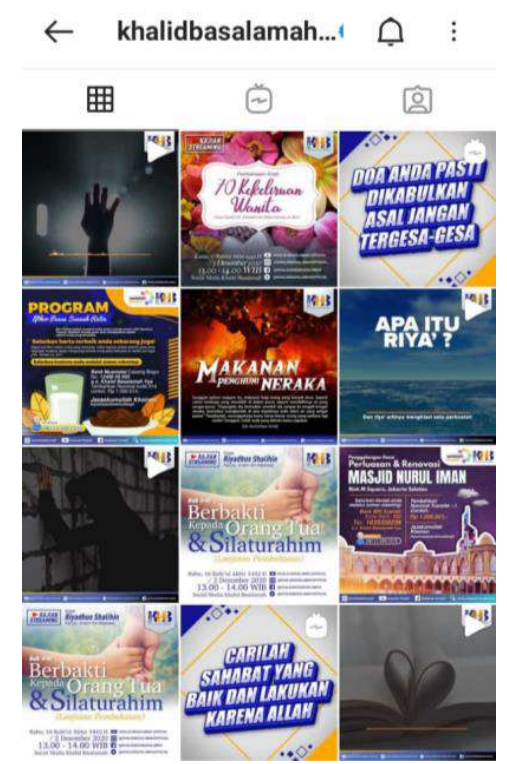

\section{Gambar 1.3 Tampilan Konten pada Akun @khalidbasalamahofficial}

Akun @khalidbasalamahofficial mengombinasikan konten yang berbentuk foto dan video. Pada unggahan berbentuk foto, antara gambar dan tulisan yang ditampilkan sengaja disesuaikan agar meninggalkan kesan yang ditonjolkan. Materi dalam foto disisipkan potongan ayat Al-Qur'an atau Hadis sahih yang sesuai dengan tema yang dibahas. Namun ada juga konten foto yang sengaja dibuat sederhana tanpa mempertimbangkan kesesuaian tema dan gambar yang dibahas. Pada unggahan foto baik poster kajian maupun pesan dakwah dibuat dengan desain grafis yang kekinian dan penggunaan warna yang cerah ala 
milenial sehingga membuat audience penasaran untuk membaca secara utuh konten tersebut. Tim digital selalu membuat kebaruan pada kontennya agar penonton tidak bosan seperti dengan membuat ilustrasi. Sementara pada unggahan yang berbentuk video, tampilan konten memperlihatkan Khalid Basalamah yang sedang berceramah. Namun yang membuat menarik, tim digital juga kerap kali membuat unggahan video yang berbeda yakni membuat ilustrasi dakwah yang menampilkan gambar video berdasarkan ucapan yang disampaikan Khalid Basalamah. Seperti pada unggahan berjudul "Kematian Mengejarmu" berhasil ditonton sebanyak 426.000 kali. Video ini menjadi unggahan dengan penonton terbanyak dibanding video-video lainnya. Artinya, penonton sangat tertarik dengan konten yang disajikan oleh akun @khalidbasalamahofficial dengan ilustrasi yang menonjolkan emosi dari apa yang disampaikan. Dilihat dari kolom komentarnya, hampir semua followers menginginkan video kemasan seperti ini banyak diunggah kembali karena menggugah hati mereka. Dapat disimpulkan, berdasarkan temuan peneliti, akun @khalidbasalamahofficial berpegang teguh dalam mengaplikasikan ajaran Salafi dalam membuat konten yang tidak melanggar syari'at. Konten yang berisikan ilustrasi sesuai dengan tema yang dibahas lebih disukai oleh para audience. Selain itu, pada setiap kontennya, tim digital memilih untuk membuat caption singkat dan tidak panjang yang menjelaskan apa yang tidak diuraikan dalam konten tersebut.

\section{Menampilkan Identitas Salafi melalui Penggunaan Hashtag}

Identitas Salafi pada akun @khalidbasalamahofficial ditunjukkan melalui penggunan hashtag. Tim KHB Digital Studio sengaja membuat identitas tersebut untuk memudahkan pengguna saat mencari konten mengenai dakwah Salafi. Adapun hashtag yang seringkali digunakan adalah \#Salafi \#khalidbasalamah. Pengguna dapat dengan mudah mencari konten dakwah Salafi melalui penggunaan hashtag tersebut. Selain menggunakan hashtag Salafi, tim juga membuat hashtag yang memang relevan dengan konten yang dibuat agar memudahkan pengguna. Penggunaan hashtag merupakan upaya tim official melakukan branding terhadap sang da'i. Hashtag tersebut diharapkan dapat mengangkat nama Khalid Basalamah dan konten yang dibuat semakin banyak dilihat dan disukai oleh para pengguna.

"Dalam membuat hashtag selalu sesuai dengan konten yang ingin disampaikan. Misalnya pembahasan terkait Corona maka kita buat hashtag \#Coronasolution atau \#Covid_19. Untuk hashtag \#Salafi yang sering ada memang sebenarnya sebagai informasi karena dakwah Khalid Basalamah sesuai dengan ajaran pemahaman para Salafi, sehingga kami menulis hashtag itu untuk menerangkan dan mengelompokkan dakwah Salafi di Indonesia. Supaya followers tahu." (Wawancara tim KHB Digital Studio, 11 Juni 2020).

\section{Menentukan Jadwal Unggah Konten}

Dalam memproduksi konten, tim KHB Digital Studio konsisten dalam menentukan jadwal konten. Tim official melihat dengan memiliki waktu unggah yang rutin tidak mengganggu followers dengan update yang berlebihan. Tim menganalisis kebiasaan pengguna dalam mengakses Instagram pada waktu-waktu tertentu. Misalnya dilihat dari jam-jam yang memang pengguna akan sering membuka Instagram. Begitupun penentuan hari juga berpengaruh pada jenis konten yang disajikan. Pada Sabtu dan Minggu, tim akan lebih banyak menyajikan konten seputar rumah tangga dan pernikahan sebab tema tersebut memang disukai dan banyak dicari oleh followers. Pengaturan waktu unggah ini 
nantinya akan mampu meningkatkan engagement serta menarik perhatian audience. Tim memilih konsisten dalam mengunggah kontennya di waktu terbaik untuk mengunggah konten sehingga membantu keberhasilan dalam menjaring audience. Sebuah penelitian yang dilakukan oleh Latergram terhadap Social Media Manager, memunculkan fakta yang cukup menarik mengenai waktu untuk mengunggah konten di Instagram.

Jadwal tayangan setiap konten telah ditentukan oleh tim official. Dengan adanya jadwal rutin ini konten yang disajikan menjadi tersistematis. Dalam pemilihan waktu untuk mengunggah, tim official juga telah mempertimbangkan sesuai dengan kebutuhan dan jamjam prime time yang seringkali followers mengakses Instagram. Pada akhirnya, sasaran dakwah yang ingin dituju tercapai. Selain ada unggahan mengenai dakwah Khalid Basalamah, akun @khalidbasalamahofficial seringkali mengunggah konten mengenai lini bisnis sang owner. Namun menurut tim official, unggahan mengenai bisnis tidak mengganggu jam tayangan unggahan dakwah. Tim membedakan jam tayang unggahan dakwah dengan bisnis. Jumlah unggahan dakwah setiap harinya sebanyak empat konten dakwah dan dua konten bisnis. Adapun tim official membagi ke dalam empat waktu dalam mengunggah dakwah:

1. Pukul 05.30 WIB

2. Pukul 10.00 WIB

3. Pukul 13.00 WIB

4. Pukul 19.00 WIB

\section{SIMPULAN}

Keterlibatan tim KHB Digital Studio dalam mengelola media sosial menjadi salah satu pendorong kesuksesan dakwah Salafi. Kehadiran tim yang membantu Khalid Basalamah mengembangkan dakwah digital membawa kekuatan tersendiri hingga populer dan dikenal banyak orang. Pembuat konten menjadi penguat pemahaman tertentu tentang Islam. Melalui unggahan pada akun Instagram @khalidbasalamahofficial, mereka berupaya menjadi agen transformasi ilmu keislaman yang bagi mereka merupakan bagian dari pemenuhannya dalam menjalankan ibadah. Tim KHB Digital Studio yakin dan sadar dengan membuat konten yang berisikan dakwah dapat membawa manfaat bagi para audience di media sosial. Tim mengamalkan dengan menyampaikan ilmu yang bermanfaat dapat menjadikan pahala. Selain membuat konten, tim official juga bisa sekaligus mempelajari ilmu syar'i sebagai bentuk pemahaman mereka kewajiban untuk menuntut ilmu. Melalui unggahan konten yang diproduksinya, pengikut menjadi agen aktif dalam menemukan cara mereka untuk menjadi Muslim yang lebih baik di dunia dengan dimediasi oleh teknologi.

Materi konten yang dibagikan oleh akun @khalidbasalamahofficial lebih memilih dengan tema-tema ringan yang seringkali dibutuhkan oleh masyarakat. Tema yang dipilih pun sengaja tidak menimbulkan kontroversial di tengah-tengah masyarakat. Ini menjadi ciri khas akun @khalidbasalamahofficial. Penggunaan hashtag \#Salafi menjadi kekuatan tersendiri bagi akun @khalidbasalamahofficial untuk menarik perhatian pengikutnya. Dengan adanya hashtag ini mempermudah followers dalam mencari materi mengenai kajian Salafi. Instagram sebagai pembuka jalan dakwah para pemula untuk menjadi penuntut ilmu. Melalui Instagram pemula yang ingin mendalami dakwah kemudian bisa terkoneksi dengan Youtube yang durasi dakwahnya lebih panjang ketimbang Instagram. Akun @khalidbasalamahofficial konsisten dalam membuat tema-tema dakwah yang ringan dan 
yang sangat berkaitan dengan kehidupan sehari-hari. Ada tiga tema besar yang diangkat oleh tim KHB Digital Studio dalam akun @khalidbasalamahofficial yakni Sirah Nabawiyah, Akhlak dan Rumah Tangga dan Pernikahan.

\section{DAFTAR PUSTAKA}

Adeni, "Institusi Televisi Keislaman: Studi atas Rodja TV sebagai Media Islam Salafi," (Tesis dan Disertasi S2 SPS, UIN Syarif Hidayatullah Jakarta, 2016).

Adeni, "Paradoks Komunikasi Dakwah Fundamentalis Salafi: Kasus Masjid Nurul Jam'iyah Jambi," dalam Jurnal Dakwah Risalah, volume 31 nomor 1 Juni 2020.

Arnus, Sri Hadijah, "Pengaplikasian Pola Computer Mediated Communication (CMC) Dalam Dakwah," dalam Jurnal Dakwah, volume 19, no.2 2018.

Bakti, Andi Faisal dan Venny Eka Meidasari, "Trendsetter Komunikasi di Era Digital: Tantangan dan Peluang Pendidikan Komunikasi dan Penyiaran Islam," dalam Jurnal Komunikasi Islam, volume 04, no. 01, Juni 2014.

Becker, Carmen, "Gaining Knowledge Salafi Activism in German and Dutch Online Forums," dalam Masaryk University Journal of Law and Technology, volume 3, no 1, 2019.

Becker, Carmen, "Muslim on The Path of Salaf Al-Salih," dalam Journal Information, Communication \& Society, volume 14, no. 8, 2011.

Cozin, Muhammad Ali, "Strategi Dakwah Salafi di Indonesia," dalam Jurnal Dakwah, volume XIV, no. 1, 2013.

Dwina, Ressi, "Mobilisasi Massa dalam Era Network Society," dalam Jurnal Pekommas, volume 16, no. 3, Desember 2013.

Fakhruroji, Moch, "Muslims Learning Islam on the Internet," Handbook of Contemporary Islam and Muslim Lives, Springer Nature Switzerland AG 2019 M. Woodward, R. Lukens-Bull, (eds.).

Hegghammer, Thomas, "Jihadi Salafis or Revolutionaries: On Religion and Politics in the Study of Islamist Militancy," dalam R Meijer, (eds.), Global Salafism: Islam's New Religious Movement, (London-New York: Hurst/Columbia University Press, 2009).

Iqbal, Asep Muhammad, "Agama dan Adopsi Media Baru: Penggunaan Internet oleh Gerakan Salafisme di Indonesia," Jurnal Komunikasi Indonesia," volume II No. 2, Oktober 2013.

J, Jamal dan Almenayes, dkk., "Religiosity and the Perceived Consequences of Social Media Usage in a Muslim Country," dalam Journal of Arts and Humanities (JAH), volume 3, no.5, May 2014.

Jawas, Yazid Abdul Qadir, Mulia Dengan Manhaj Salaf, cetakan ke-25., (Bogor: Pustaka AtTaqwa.

Jonge, De and Kaptein Nico, dkk., Transcending and Borders Arabs, Politics, Trade and Islam Southeast Asia, (Leiden: KITLTV Press, 2002).

Kaplan, Andreas M dan Michael Haenlein, dkk., Users of the World, Unite! The Cahallanges and Opportunities of Social Media, Business Horizons 53 (1), 2010.

Littlejohn, Stephen W and A.F Karen, dkk., Encyplopedia of Communication Theory, volume I, (California: Sage Publications, 2009).

McQuail, Denis, Teori Komunikasi Massa Suatu Pengantar. Penerjemah Agus Dharma dan Aminuddin Ram, (Jakarta: Penerbit Erlangga, 1987).

Moleong, Lexy J, Metode Penelitian Kualitatif, (Bandung: Remaja Rosda Karya, 2007).

Mustofa, "Peran Hashtag (\#) dalam Media Sosial Sebagai Upaya Branding Pustakawan," dalam Libraria, 2019, Vol 7, no. 1, Insitut Seni Indonesia (ISI).

Nisa, Eva F, "Creative and Lucrative Da'wa: The Visual Culture of Instagram amongs Female Muslim Youth in Indonesia," dalam Religious Studies, Victoria University of Wellington. 
Romario dan Lisda Aisyah, dkk., "Komik Islam di Media Sosial Instagram: Dakwah Kreatif Melalui Komik," Jurnal Studi Islam, volume 6, no. 2, 2019.

Rozalia, Tasman, "Radio Rodja: Kontestasi Ideologi Salafi di Ranah Siaran," dalam Dakwah: Jurnal Kajian Dakwah dan Kemasyarakatan, volume 22, no, 2), 2018.

Setiadi, Ahmad, "Pemanfaatan Media Sosial Untuk Efektivitas Komunikasi," dalam Jurnal Humaniora Universitas Bina Sarana Informatika, volume 16, nomor 2, 2016.

Silvia, Mega. dkk., "Strategi Content Creator pada Dakwah di Media Sosial (Studi Kasus pada Akun Instagram @pejuang.mahar)," dalam Jurnal Communications Department, Desember 2019.

Sunesti, Yuyun, dkk., "The Sunnah Lake of Muslimah: Salafi Women, The Manhaj and Online Media," dalam Journal Humanities \& Social Sciences Reviews, volume 6, no. 3, 2018.

Syukir, Asmuni, Dasar-Dasar Strategi Dakwah Islam, (Surabaya : Al-Ikhlas, 1983).

Tubbs, Stewart L., et. Al, Human Communication, (Bandung: PT Remaja Rosdakarya, 1996).

Wahid, Din, "Challenging Religious Authority The Emergence of Salafi Ustadhs in Indonesia," dalam Journal of Indonesian Islam. Volume 06, no. 2 Desember 2012.

Wally, E \& S Koshy, "The Use of Instagram As A Marketing Tool By Emirati Female Entrepreneurs: An Exploratory Study," dalam International Business Research Conference, 2014.

Zulkifli, Muhammad, Ilmu Dakwah, (Makassar : Pustaka Al-Zikra, 2005).

CNN Indonesia, "Anak Muda Hijrah di Mata NU dan Muhammadiyah," artikel diakses pada 14 Februari 2020 darihttps://www.cnnindonesia.com/nasional/20190516190532-20395594/anak-muda-hijrah-di-mata-nu-dan-muhammadiyah

Alle Ceambur, "Tips and Tricks to Build a Seamless Instagram Content Strategy," artikel diakses pada 30 November 2020 dari https://nealschaffer.com/instagram-contentstrategy/

Michael Stelzner, "Instagram Content Strategy: Creating Content That Draws Customers to You," artikel diakses pada 1 Desember 2020 dari https://www.socialmediaexaminer.com/instagram-content-strategy-creating-contentthat-draws-customers-to-you-alex-tooby/

Wahyunanda Kusuma Pertiwi, "Sebanyak Inikah Jumlah Pengguna Instagram di Indonesia," artikel diakses pada $20 \quad$ Februari 2020 dari https://tekno.kompas.com/read/2019/12/23/14020057/sebanyak-inikah-jumlahpengguna-instagram-di-indonesia.

Akun Instagram official @khalidbasalamahofficial. Diakses pada 6 September 2020 pukul 11.28 WIB dari https://instagram.com/khalidbasalamahofficial?igshid=1ud4e1yg7sz43. Atang Setiawan (Anggota Sat Indag Dit Reskrimsus PMJ), "Pelangggaran Hak Kekayaan Intelektual", artikel diakses pada 3 Juni 2020 dari www.reskrimsus.metro.polro.go.id/info/informasi

Muhyiddin, "Ulama Hadramaut Berperan Penting Dalam Penyebaran Islam," artikel diakses pada 3 Juni 2020 dari https://republika.co.id/berita/dunia-islam/islamnusantara/19/06/30/ptx6tp313-ulama-hadramaut-berperan-penting-dalampenyebaran-islam

Ma'had Al-Birr, "Sejarah Berdirinya Ma'had Al-Birr," artikel diakses pada 24 Juni 2020 dari http://albirr.almaahid.com/index.php/main/view/2159/sejarah 2 
Ahmad Zenudin, "Mengapa Para Dai Bisa Amat Populer di Media Sosial," artikel diakses pada 13 Juli 2020 dari http://www.google.com/amp/s/amp.tirto.id/mengapa-para-dainosa-amat-populer-di-media-sosial-cCox.

Wawancara Pribadi dengan Khalid Basalamah, Jakarta, 22 Juni 2020.

Wawancara Pribadi dengan Tim KHB Digital Studio, Dimas Rizki Agustian dan Dimas Pradipta, Jakarta, 11 Juni 2020. 